\title{
ENDOMETRIAL SAFETY OF ULIPRISTAL ACETATE TREATMENT FOR SYMPTOMATIC UTERINE FIBROIDS IN PREMENOPAUSAL WOMEN - A SYSTEMATIC REVIEW
}

\author{
LIANA PLEȘ ${ }^{1,2}$, DELIA CARP ${ }^{2}$, ROMINA MARINA SIMA ${ }^{1,2} *$, ALEXANDRA MIRICĂ ${ }^{1,3}$, \\ ANCA-DANIELA STĂNESCU ${ }^{1,2}$, DENISA-OANA BĂLĂLĂU ${ }^{1,2}$, CRISTIAN BĂLĂLĂU ${ }^{1,4}$ \\ 1 "Carol Davila" University of Medicine and Pharmacy, Bucharest, Romania \\ 2 "Sf. Ioan" Hospital, "Bucur" Maternity, Bucharest, Romania \\ 3 "C. I. Parhon" National Institute of Endocrinology, Bucharest, Romania \\ 4 “Sf. Pantelimon" Emergency Clinical Hospital, Department of Surgery, Bucharest, Romania
}

*corresponding author: romina.sima@yahoo.es

\begin{abstract}
The aim of the present article was to evaluate endometrial safety of the ulipristal acetate (UPA) treatment for uterine symptomatic fibroids by reviewing the relevant studies and to provide confidence in SPRM (Selective Progesterone Receptor Modulators) clinical use. We designed a review protocol according to PRISMA guidelines and electronic databases search. The databases searched were PubMed, Embase and Cochrane for terms "ulipristal acetate", "endometrium" and "fibroid" or synonyms. After screening, 41 full-text studies were retained, with 9 included selected: 7 randomized controlled, one prospective observational case control and one off label including 1997 patients treated with UPA. Dosage, interval and endometrial aspects at biopsy were described. UPA-induced non-physiological histological changes of the endometrium were reported by 5 studies. The overall quality of the studies was good. No premalignant or malignant endometrial changes were reported. Evidences provided by the study are consistent - UPA can be prescribed for conservative or pre-surgical treatment of fibroids without concern on possible endometrial malignancies.
\end{abstract}

\section{Rezumat}

Scopul articolului a fost de a evalua siguranța tratamentului cu ulipristal acetat (UPA) asupra endometrului pentru fibromiomul uterin simptomatic, realizat prin revizuirea studiilor relevante, și de a certifica utilizarea clinică a SPRM (modulatori selectivi ai receptorilor progesteronici). A fost creat un protocol de evaluare conform ghidului PRISMA şi am inclus baze de date electronice. Bazele de date verificate au fost PubMed, Embase şi Cochrane pentru termenii „,ulipristal acetat”, „endometru” și „fibromiom” sau sinonime. După screening, au fost selectate 41 studii complete: 9 au fost incluse dintre care 7 randomizate, unul prospectiv observațional şi unul caz-control, evaluând în total 1997 paciente tratate cu UPA. $\mathrm{Au}$ fost descrise dozele, intervalul şi aspectele endometriale la biopsie. Modificările histologice nefiziologice induse de UPA ale endometrului au fost identificate în 5 studii. Calitatea generală a studiilor a fost bună. Nu au fost raportate modificări endometriale premalignate sau maligne. Studiile au dovedit că UPA poate fi prescris ca tratament conservator sau preoperator al fibromioamelor, confirmând siguranța în raport cu malignitățile endometriale posibile.

Keywords: ulipristal acetate, endometrial safety, PAEC, uterine fibroids treatment

\section{Introduction}

Progesteron receptors antagonists were introduced in practice as contraceptive drugs in the early 1990 by Philibert et al and since then a multitude of similar drugs with PR (progesterone receptor) agonist and antagonist effects were produced [1]. Drugs with both actions and various indications generally known as Selective Progesteron Receptor Modulators (SPRMs) were described in 2000 by Elger and other authors and clinical applications were enlarged [2,3]. According to Chabbert-Buffet, the SPRM's indication can be largely structured as gynaecological (emergency contraception, medical termination of pregnancy, menstrual regulation, endometriosis and fibroid treatment) and non- gynaecological (for Cushing's syndrome, glucocorticoid antagonism, major depression with psychotic features, Alzheimer's disease, steroid receptor-containing tumours) [4].

Ulipristal acetate (UPA) with research name CDB/VA 2914 was introduced for contraceptive purposes and leiomyomas treatment in 2009 by the EMA (European Medicines Agency) and in 2010 was approved by FDA (U.S. Food and Drug Administration).

UPA acts on endometrium and myometrium as a dose dependent PR antagonist and agonist. Its PR antagonist action has a contraceptive effect, either in unique dose (30 $\mathrm{mg}$ as emergency contraception) $[3,4]$, as continuously daily dose of $5 \mathrm{mg}$ or $10 \mathrm{mg}$ 
(inhibition of ovulation and amenorrhea) or vaginal ring, that is not yet available $[3,5]$.

UPA antagonist action on endometrium can control bleeding by opposing endometrial proliferation and amenorrhea induction in up to $81 \%$ of patients, but the mechanism of action on the intact endometrium is not fully understood [3-5].

Pearl I, II and III studies demonstrated that UPA in doses of $5 \mathrm{mg}$ or $10 \mathrm{mg}$ daily for three months has antiproliferative, antifibrotic and proapoptotic effects on the myometrium, reducing the fibroid volume prior to surgery $[6,7]$.

Endometrial antiproliferative effects will lead to specific histological changes represented by: dyssynchronous growth, cystically dilated glands with low mitotic activity, apoptosis and epithelial distortion [8]. Other studies confirmed the unusual appearance of the endometrium after SPRM which do not correlate with other similar drugs. Those specific endometrial aspects were labelled as PAEC (progesterone selective receptor associated endometrial changes). In a large study on 1638 endometrial biopsies after UPA or placebo, Williams et al performed an exhaustive analysis of the endometrial morphology and compared PAEC with unopposed oestrogen endometrial changes and endometrial hyperplasia. They concluded that the lack of nuclear changes, the low mitotic activity, the benign stromal alteration and the reversibility after treatment cessation are the main features of PAEC [9]. The PR antagonist effect of the UPA can lead to an oestrogen exposure of the endometrium unbalanced by progesterone and thus endometrial hyperplasia and even malignancies can occur raising a legitimate concern towards the drug safety on the endometrium. Considering the reduced number of patients with uterine fibroids treated so far in our country, PAEC can raise considerable problems for pathologists and gynaecologists due to possible confusions with premalignant conditions as endometrial hyperplasia or even malignancy of the endometrium. Therefore, this study aims to evaluate the safety of the UPA presurgical treatment of the uterine fibroids by reviewing the relevant studies and to provide confidence in SPRM clinical use.

\section{Materials and Methods}

This systematic review was structured according to the PRISMA guidelines [10]. No pre-existent protocol was used. The inclusion criteria for review (eligibility) were: population - studies participants - premenopausal women with uterine fibroids; intervention UPA administration for fibroid treatment irrespective of dose and length of treatment; comparison - no comparison was included; outcome: the main outcome evaluation was endometrial histological aspect after UPA treatment (biopsy or postsurgical).

All types of studies (prospective, retrospective, case control, systematic review) on UPA endometrial changes published in peer reviewed journals without language restriction from 2008 up to September 2017 were considered. We designed a review protocol according to PRISMA guidelines and the database search was electronic.

The databases considered were PubMed, Embase and Cochrane and the search was electronically performed for terms "ulipristal acetate", "endometrium" and "fibroid/myomas, leiomyoma" or synonyms. If the abstracts were relevant for the inclusion criteria, the full papers were extracted from the original publication. We excluded the titles without corresponding fulltext. After collecting the data we excluded duplicated studies, the remaining titles were analysed for the inclusion criteria. When there was a disagreement concerning a study inclusion, it was solved by discussion or by a third part intervention. Quality assessment of individual studies was performed according to the protocols for bias assessment according to their type. RCT's risk was assessed according to Cochrane Collaboration's "Risk of Bias" tool and classified in: low risk for bias, high risk for bias and uncertain risk. The following parameters were used for classification: random sequence generation, allocation concealment, blinding of participants and personnel, blinding of outcome assessment, incomplete outcome, data and selective reporting [11]. For non-randomized studies, as case control observational, the two main biases concerned were assessed - selection bias and information bias and the risk of bias expressed as "away from null" or "towards the null" [12].

\section{Results and discussions}

Database search provided 2706 items from which 304 were excluded as duplicates. After abstract assessment, 41 studies were retained and considered relevant. The full-text was searched and retrieved and analysed by three researchers. After evaluation, 32 records were excluded for various reasons: 12 articles were excluded according to the type at high risk of bias or not containing reliable data (case reports, letters to the editor), for 9 reported no biopsy, in 11 cases the outcome of the study was not eligible. 9 studies that included endometrial biopsy were finally meeting the inclusion criteria. The selected studies included a number of 1997 participants. Table I shows the characteristics of each study. 
Studies characteristics

\begin{tabular}{|c|c|c|c|c|c|c|c|c|}
\hline \multirow[t]{2}{*}{ Author, year } & \multirow[t]{2}{*}{ Design } & \multirow[t]{2}{*}{$\begin{array}{c}\text { No. } \\
\text { Participants }\end{array}$} & \multirow[t]{2}{*}{\begin{tabular}{|l|}
$\frac{\text { Mean age }}{\text { or age }}$ \\
ranges
\end{tabular}} & \multirow[t]{2}{*}{ UPA dosage } & \multirow[t]{2}{*}{\begin{tabular}{|l|}
$\frac{\text { Period of }}{\underline{U P A}}$ \\
treatment
\end{tabular}} & \multirow[t]{2}{*}{ Placebo } & \multicolumn{2}{|c|}{$\frac{\underline{\text { No. }}}{\frac{\text { Endometrial }}{\text { biopsies }}}$} \\
\hline & & & & & & & D & $\mathbf{E}$ \\
\hline $\begin{array}{l}\text { 1.CDB-2914 for uterine } \\
\text { leiomyomata treatment } \\
\text { E.D. Levens, } 2008\end{array}$ & RCT & 22 & $33-50$ & $\begin{array}{c}10 \mathrm{mg} \text { or } 20 \\
\mathrm{mg} \text { daily }\end{array}$ & \begin{tabular}{|c|}
$\begin{array}{c}3 \text { cycles or } \\
90-102 \\
\text { days }\end{array}$ \\
\end{tabular} & Yes & 0 & 1 \\
\hline $\begin{array}{l}\text { 2.UPA versus placebo for fibroid } \\
\text { treatment before surgery } \\
\text { J. Donnez, PEARL I, } 2012\end{array}$ & $\begin{array}{c}\text { DB } \\
\text { RCT }\end{array}$ & 242 & 41 & $\begin{array}{c}5 \mathrm{mg} \text { or } 10 \\
\mathrm{mg} \text { daily }\end{array}$ & 13 weeks & Yes & 1 & 1 \\
\hline $\begin{array}{l}\text { 3.UPA versus leuprolide acetate } \\
\text { for UF } \\
\text { J. Donnez, PEARL II, } 2012\end{array}$ & $\begin{array}{l}\mathrm{RCT} \\
\mathrm{DB}\end{array}$ & 307 & 40 & $\begin{array}{c}5 \mathrm{mg} \text { or } 10 \\
\mathrm{mg} \text { daily }\end{array}$ & 13 weeks & $\begin{array}{c}\text { Yes }+ \\
\text { Leuprolide }\end{array}$ & 1 & 1 \\
\hline $\begin{array}{l}\text { 4.Endometrial morphology after } \\
\text { treatment of UF with the SPRM, } \\
\text { UPA } \\
\text { A.R. Williams, } 2012\end{array}$ & $\begin{array}{c}\mathrm{RCT} \\
\mathrm{DB}\end{array}$ & 546 & & $\begin{array}{l}5 \text { or } 10 \mathrm{mg} \\
\text { of UPA } \\
\text { daily }\end{array}$ & 13 weeks & $\begin{array}{c}\text { Yes }+ \\
\text { gonadotropin- } \\
\text { releasing } \\
\text { hormone } \\
\text { agonist }\end{array}$ & & 2 \\
\hline $\begin{array}{l}\text { 5.Long-term treatment of uterine } \\
\text { fibroids with UPA } \\
\text { J. Donnez, PEARL III, } 2014\end{array}$ & $\mathrm{OL}$ & 209 & 40 & $10 \mathrm{mg}$ daily & 12 weeks & $\begin{array}{l}\text { Yes }+10 \mathrm{mg} \\
\text { progestin } \\
\text { NETA }\end{array}$ & 0 & 1 \\
\hline $\begin{array}{l}\text { 6.Radiographic and histopathologic } \\
\text { endometrial characteristics of women } \\
\text { undergoing treatment with UPA } \\
\text { T.R. Segal, } 2014\end{array}$ & $\begin{array}{l}\mathrm{RCT} \\
\mathrm{DB}\end{array}$ & 54 & 43 & $\begin{array}{c}10 \mathrm{mg} \text { or } 20 \\
\mathrm{mg} \text { daily }\end{array}$ & 12 weeks & Yes & 0 & 1 \\
\hline $\begin{array}{l}\text { 7.Efficacy and safety of repeated } \\
\text { use of UPA in UF } \\
\text { J. Donnez, PEARL IV, } 2014\end{array}$ & $\begin{array}{l}\text { DB } \\
\text { RCT }\end{array}$ & 451 & 41 & $\begin{array}{c}5 \text { or } 10 \mathrm{mg} \\
\text { daily }\end{array}$ & 12 weeks & No & 0 & 1 \\
\hline $\begin{array}{l}\text { 8.First US-based phase } 3 \text { study of } \\
\text { UPA for symptomatic UF: results } \\
\text { of VENUS-I } \\
\text { J. Simon, } 2016\end{array}$ & $\begin{array}{l}\text { PCS } \\
\text { RCT } \\
\text { DB }\end{array}$ & 157 & $18-50$ & $\begin{array}{c}5 \text { or } 10 \mathrm{mg} \\
\text { daily }\end{array}$ & 12 weeks & Yes & 0 & 1 \\
\hline $\begin{array}{l}\text { 9. SPRM UPA and its effects on } \\
\text { the human endometrium. } \\
\text { L.H. Whitaker, } 2017\end{array}$ & OS-CC & 9 & $39-49$ & $5 \mathrm{mg}$ daily & $\begin{array}{l}9-12 \\
\text { weeks }\end{array}$ & No & 1 & 1 \\
\hline
\end{tabular}

$\mathrm{RCT}=$ randomised controlled study; PCS = prospective cohort study; UPA = ulipristal acetate; OS-CC = observational case control; $\mathrm{UF}=$ uterine fibroids; $\mathrm{SPRM}=$ selective progesterone receptor modulator; $\mathrm{NETA}=$ norethisterone acetate; $\mathrm{DB}=$ double $\mathrm{blind}$

There were 7 RCT, 1 observational case control study and one RCT off label (OF) study. Histological findings of the studies are indicated in Table II.

The first study that reported endometrial biopsy after SPRM for symptomatic uterine fibroids performed by Levens in 2008 provided scarce information on endometrial PAEC [13]. They reported only one benign hyperplasia for a $10 \mathrm{mg}$ dose in women that was amenorrhoeic for the entire 3-months course of UPA treatment. No further information concerning the endometrial aspect after surgery was provided. The most important evidences came from PEARL I, II, II, and IV studies that were performed from 2008 to 2014 in 7 countries. The histological changes of the endometrium during UPA and after treatment were more elaborated in Donnez et al. studies [6, 7 , 14, 15].

In PEARL I study [6], UPA $5 \mathrm{mg}, 10 \mathrm{mg}$ was given daily for 13 weeks prior to the surgery treatment of fibroids. The study was blinded and randomized with a placebo group. Endometrial biopsies were performed at the end of treatment (13 weeks). PAEC were observed in $62 \%$ of $5 \mathrm{mg}$ group, $57 \%$ of the $10 \mathrm{mg}$ group and $6 \%$ in the placebo with no malignant or premalignant lesions. After 38 weeks (follow up for patients that did not undergo hysterectomy) there was no endometrial abnormality in the treated group, but complex atypical hyperplasia.

In PEARL II [7], the UPA $5 \mathrm{mg}$ or $10 \mathrm{mg}$ daily for 13 weeks was double-blind compared to leuprolide acetate $3.75 \mathrm{mg}$ once monthly for 13 weeks in the treatment of uterine fibroids. At the end of the treatment, the PAEC were found after endometrial biopsy in $58 \%$ of $5 \mathrm{mg}$ group, $59 \%$ of the $10 \mathrm{mg}$ group and $12 \%$ in the leuprolide group. At the follow up, the biopsy described: 1 case of simple hyperplasia in the $5 \mathrm{mg}$ group, $6 \%$ PAEC in the 5 $\mathrm{mg}$ group and $7 \%$ in the $10 \mathrm{mg}$, but no malignant or premalignant changes. 
Reported histological changes at any moment during and after ulipristal acetate use

\begin{tabular}{|c|c|c|c|c|c|c|}
\hline & \multicolumn{2}{|c|}{$P A E C$} & \multicolumn{2}{|c|}{ Hyperplasia } & \multicolumn{2}{|c|}{ Adenocarcinoma } \\
\hline & During treatment & Follow-up & During treatment & Follow-up & During treatment & Follow-up \\
\hline $\begin{array}{l}\text { 1.CDB-2914 for uterine } \\
\text { leiomyomata treatment } \\
\text { E.D. Levens, } 2008(\mathrm{~N}=22)\end{array}$ & NR & NR & NR & $\begin{array}{c}4.5 \% \text { of all } \\
8 \% \text { of } \\
\text { UPA }\end{array}$ & NR & $0 \%$ \\
\hline $\begin{array}{l}\text { 2.UA versus placebo for } \\
\text { fibroid treatment before } \\
\text { surgery } \\
\text { J. Donnez, PEARL I, } 2012 \\
(\mathrm{~N}=242)\end{array}$ & $\begin{array}{l}\text { UPA } 5 \mathrm{mg} 62 \% \\
\text { UPA } 10 \mathrm{mg} 57 \%\end{array}$ & $0 \%$ & $0 \%$ & $0 \%$ & $0 \%$ & $0 \%$ \\
\hline $\begin{array}{l}\text { 3.UA versus leuprolide } \\
\text { acetate for UF } \\
\text { J. Donnez, PEARL II, } 2012 \\
(\mathrm{~N}=281)\end{array}$ & $\begin{array}{l}\text { UPA } 5 \mathrm{mg} \mathrm{58 \%} \\
\text { UPA } 10 \mathrm{mg} \mathrm{59 \%}\end{array}$ & $\begin{array}{l}\text { UPA } 5 \mathrm{mg} \\
6 \%-7 \% \\
\text { PAEC } \\
\text { UPA } 10 \mathrm{mg} \\
6 \%-7 \% \\
\text { PAEC }\end{array}$ & $\begin{array}{l}\text { UPA } 5 \mathrm{mg} 1 \% \\
\text { UPA } 10 \mathrm{mg} 0 \%\end{array}$ & $0 \%$ & $0 \%$ & $0 \%$ \\
\hline $\begin{array}{l}\text { 4.Endometrial morphology } \\
\text { after treatment of UF with } \\
\text { the SPRM, UPA } \\
\text { A.R. Williams, } 2012 \\
(\mathrm{~N}=546)\end{array}$ & $\begin{array}{l}\text { UPA } 5 \mathrm{mg} 74 \% \\
\text { UPA } 10 \mathrm{mg} 72 \%\end{array}$ & $\begin{array}{l}\text { UPA } 5 \mathrm{mg} \\
14 \% \\
\text { UPA } 10 \mathrm{mg} \\
12 \%\end{array}$ & $0.00017 \%$ & $0 \%$ & $0 \%$ & $0 \%$ \\
\hline $\begin{array}{l}\text { 5.Long-term treatment of } \\
\text { UF with UPA } \\
\text { J. Donnez, PEARL III, } 2014 \\
(\mathrm{~N}=209)\end{array}$ & NR & $25.6 \%$ & NR & $0 \%$ & NR & $0 \%$ \\
\hline $\begin{array}{l}\text { 6.Radiographic and } \\
\text { histopathologic endometrial } \\
\text { characteristics of women } \\
\text { undergoing treatment with } \\
\text { UPA } \\
\text { T.R. Segal, } 2014(\mathrm{~N}=54)\end{array}$ & $6.7 \%$ & NR & $6.7 \%$ & NR & NR & $0 \%$ \\
\hline $\begin{array}{l}\text { 7.Efficacy and safety of } \\
\text { repeated use of UPA in UF } \\
\text { J. Donnez, PEARL IV, 2014 } \\
(\mathrm{N}=451)\end{array}$ & NR & $\begin{array}{c}\text { UPA } 5 \mathrm{mg} \\
16.3 \% \\
\text { UPA } 10 \mathrm{mg} \\
19.2 \% \\
\end{array}$ & NR & $\begin{array}{c}\text { UPA } 5 \mathrm{mg} \\
0.6 \% \\
\text { UPA } 10 \\
\text { mg } 1.1 \% \\
\end{array}$ & NR & $\begin{array}{l}\text { UPA } 5 \mathrm{mg} \\
0.6 \% \\
\text { UPA } 10 \\
\text { mg } 0 \% \\
\end{array}$ \\
\hline $\begin{array}{l}\text { 8.First US-based phase } 3 \\
\text { study of UPA for } \\
\text { symptomatic UF: results } \\
\text { of VENUS-I } \\
\text { J. Simon, } 2016(\mathrm{~N}=157)\end{array}$ & NR & NR & $0 \%$ & $0 \%$ & $0 \%$ & $0 \%$ \\
\hline $\begin{array}{l}\text { 9.SPRM UPA and its effects } \\
\text { on the human endometrium. } \\
\text { L.H. Whitaker, } 2017(\mathrm{~N}=9)\end{array}$ & UPA $5 \mathrm{mg} \mathrm{100 \%}$ & $0 \%$ & $0 \%$ & $0 \%$ & $0 \%$ & $0 \%$ \\
\hline
\end{tabular}

$\mathrm{UPA}=$ ulipristal acetate; $\mathrm{UF}=$ uterine fibroids; SPRM = selective progesterone receptor modulator; $\mathrm{NR}=$ not reported.

In PEARL III [14] the treatment for symptomatic uterine fibroids consisted of $10 \mathrm{mg}$ UPA in one or two open-label courses immediately followed by ten days double-blind oral progestin norethisterone acetate (NETA), $10 \mathrm{mg}$ once daily or matching placebo. NETA administration was hypothesized to enhance PAEC reversibility at the end of treatment defined as the return of menstrual period. The study had an extension. In the PEARL III two endometrial biopsies were performed at inclusion and two weeks after the first menstrual bleeding day post treatment course. In the extension study the second biopsy was taken two weeks after the extended course (course four). There were no cases of endometrial hyperplasia or adenocarcinoma reported after the four course treatment with UPA $10 \mathrm{mg}$ daily in both PEARL III and PEARL III extension. The histological non-physiological changes of the endometrium were found in a reduced number in the NETA group compared to baseline (PEARL III ulipristal-placebo $28.3 \%$ vs. 8.2\%, ulipristalNETA $22.6 \%$ vs. 13.8\%, PEARL III extension ulipristalplacebo $30.8 \%$ vs. $7.1 \%$, ulipristal-NETA $26.3 \%$ vs. $14.3 \%$ ).

PEARL IV [15] explored the efficacy and safety of repeated use of $5 \mathrm{mg}$ or $10 \mathrm{mg}$ UPA given daily per $o s$ for two repeated 12-week treatment courses. The second course commenced with the second offtreatment menstruation. Endometrial changes were assessed before the beginning of the first course and 10 - 18 days after the first menses at the end of 
the treatment (second course). After treatment, PAEC were reported in $16.3 \%$ and $19.2 \%$ of the $5 \mathrm{mg}$ and $10 \mathrm{mg}$ groups, but no malignant or premalignant changes of the endometrium. Three cases of endometrial hyperplasia were reported: 1 in the $5 \mathrm{mg}$ group $(0.6 \%)$ and 2 in the $10 \mathrm{mg}$ group (1.1\%), respectively (no p-value available). At follow-up, the biopsy revealed, one aspect of adenocarcinoma reported in the group with the $5 \mathrm{mg}$ dose. The initial biopsy was retrospectively evaluated and it proved that the lesion was already present before treatment, but oversight.

Williams et al. in 2012 [9] conducted an extensive study to appraise the endometrial changes in 2 Phase III RCT (PEARL I and II). There were 546 patients treated for uterine fibroids with 5/10mg UPA for 13 weeks. The study was blinded with a group receiving placebo or gonadotropin-releasing hormone (GnRH) agonist. Endometrial by biopsies were assessed at study inclusion, at the end of treatment (13 weeks) and after treatment-free follow-up ( 38 weeks) by 3 independently pathologists according to a pre-set morphologic scheme. In PEARL I, at the end of treatment, only benign changes of the endometrium and no endometrial hyperplasia, adenocarcinoma or premalignant changes were reported by any of the pathologists. At the follow up free treatment interval, there was a complex atypical hyperplasia in one case $(2.6 \%)$ of the placebo group and one benign functional polyp in the $5 \mathrm{mg}$ UPA group. In PEARL II, at the end of the treatment, one simple not atypical hyperplasia was found in the group with $5 \mathrm{mg}$ UPA and no abnormal endometrial changes. At the end of the treatment (38 weeks) there was one simple endometrial hyperplasia in the GnRH-agonist and no endometrial polyps, atypical hyperplasia, adenocarcinomas, or other malignant neoplasms [9].

In a RCT study from 2008 and published in 2014, Segal et al. [16] appraised the endometrial changes

in 54 patients receiving 10 or $20 \mathrm{mg}$ UPA prior to surgery for 9 - 12 weeks. The biopsies were obtained by surgical intervention and showed PAEC in $6.7 \%$ of cases, simple hyperplasia in $6.7 \%$ cases and no malignant or premalignant lesions.

Simon et al. published in 2016 a RCT study in the VENUS I project on 157 patients who received 5 - 10 mg UPA vs. placebo for 12 weeks for symptomatic uterine fibroids. The main outcome of the study addressed to the adverse reactions, mainly cardiovascular symptoms and, as secondary outcome, endometrial changes were evaluated. They found no hyperplasia or malignancy after treatment [17].

Whitaker et al. conducted a recent study [18] in order to assess by immunohistology the UPA treatment effects on the endometrial gene expression. 9 biopsies were sampled from premenopausal women treated with 5 mg UPA daily 9 - 12 weeks for symptomatic uterine fibroids. The control group consisted in 9 proliferative and 9 secretory samples of endometrium of pre-menopausal women of similar age, who underwent hysterectomy for symptomatic fibroids. The samples were retrieved from tissue archives. The control group had regular menstrual cycles and no preoperative treatment. The samples were assessed for progesterone receptor (PR), progesterone receptor protein isoform $\mathrm{B}(\mathrm{PRB})$, androgen receptor (AR), oestrogen receptor alpha $(\mathrm{ER} \alpha)$, FOXO1, HAND2, HOXA10, PTEN and Ki67.

Analysis of stromal cells showed a significant reduction in Ki67 positive cells in secretory phase and in UPAtreated samples, the conclusion being that UPA does not increase the proliferative activity of the endometrium.

Risk of bias in the included studies

The overall quality of the included randomized clinical trials was considered good (Table III).

Table III

Qualitative assessment of the RCT studies

\begin{tabular}{|c|c|c|c|c|c|c|}
\hline Study & $\begin{array}{c}\text { Random } \\
\text { sequence } \\
\text { generation }\end{array}$ & $\begin{array}{c}\text { Allocation } \\
\text { concealment }\end{array}$ & $\begin{array}{c}\text { Blinding of } \\
\text { participants } \\
\text { and personnel }\end{array}$ & $\begin{array}{l}\text { Blinding of } \\
\text { outcome } \\
\text { assessment }\end{array}$ & $\begin{array}{c}\text { Incomplete } \\
\text { outcome }\end{array}$ & $\begin{array}{l}\text { Data and } \\
\text { selective } \\
\text { reporting }\end{array}$ \\
\hline PEARL I & + & + & + & + & + & + \\
\hline PEARL II & + & + & + & + & + & + \\
\hline PEARL III & $?$ & + & + & + & + & + \\
\hline PEARL IV & + & + & + & + & + & $?$ \\
\hline Williams & + & + & + & + & + & + \\
\hline Levens & + & + & + & $?$ & + & $?$ \\
\hline Segal & + & $?$ & + & + & $?$ & $?$ \\
\hline Low risk & 85.71 & 85.71 & 100 & 85.71 & 85.71 & 57.14 \\
\hline Unclear risk & 14.29 & 14.29 & 0 & 14.29 & 14.29 & 42.86 \\
\hline High Risk & 0 & 0 & 0 & 0 & 0 & 0 \\
\hline Overall risk of bias & $\mathrm{L}$ & $\mathrm{L}$ & $\mathrm{L}$ & $\mathrm{L}$ & $\mathrm{L}$ & $\mathrm{M}$ \\
\hline
\end{tabular}

“+” = low risk of bias, "?” = unclear risk of bias, "." = high risk of bias

In three out of seven included RCT we could not access the link to the study protocol and they were included as an unclear risk of reporting bias.
The only observational study (Whitaker) has a risk of bias away from the null considering the selection control cases and the low number of participants. 
The cohort studies provided any information on possible study confounders; therefore they were all classified as high risk of bias.

The present systematic literature review appraised the endometrial safety of the UPA administration for uterine fibroids on short or long term, prior to surgery or for bleeding control. Dosage, interval and endometrial aspects at biopsy were described. UPA induced no physiological histological changes of the endometrium (PAEC), as reported by 5 out of the 9 studies $[6,7,9$, 15-18] and were found at follow up biopsies in variable rates from $6.7 \%$ to $25.6 \%$, seeming that there is no consistent correlation with the dose $(10 \mathrm{mg})$ and prolonged treatment $[6,7,15-18]$. The studies are therefore consistent for the reversibility of the endometrial changes. Considering the surgery that intervenes in the majority of cases, the changes are even less ominous.

The PAEC changes should not be confused with hyperplasia or other premalignant or malignant endometrial lesions, and can be recognized by the following main characteristics: low mitotic activity in both glands and stroma, abortive sub-nuclear vacuoles, apoptosis, absence of stromal breakdown and glandular crowding and cystically dilated glands lined by flattened epithelium without nuclear pseudo-stratification [9]. By comparison, the histologic features of endometrial hyperplasia presents diffuse epithelial architectural disorders with frequent mitosis, large rounded and stratified nuclei, stromal modifications with thrombi and foaming [9].

Hyperplasia was found in only 8 patients treated with UPA from the 1997 patients [6, 7, 15-18]. 7 cases of hyperplasia were simple and one atypical which was resolved after treatment cessation. One case of endometrial adenocarcinoma was found [15], but the retrospective evaluation of the baseline biopsy proved that the lesion existed at the beginning of the treatment and there is no report concerning the follow up of the patient. In that context the malignant lesion cannot be related to UPA administration.

Strengths and limitations

Possible limitations of the review can be the low number of studies identified and the exclusion of some types of studies as case report. However the high risk of bias and the limited information provided by such studies did not justify their inclusion.

Other limitations can occur from the heterogeneity of the endometrial description in the early studies and the variation in UPA dosage (5 mg, $10 \mathrm{mg}, 20 \mathrm{mg}$ ). Some of the studies did not performed baseline biopsy; others did not proceed with follow up evaluation of the endometrium. Only 151 follow up biopsies were performed in PEARL I and II and 8 in PEARL III for patients that did not undergo hysterectomy. The strength of the review consists in the important literature search, different search terms and the follow of the methodological guidelines for systematic review recommended by PRISMA guidelines [10].

No meta-analysis could be performed due to the limited numerical data provided.

Comparison with other reviews

The effect of SPRM on endometrium was evaluated in other reviews. The studies addressed specific issues.

For instance, Wagenfeld et al. focused on the endometrial changes due to all progesterone receptor modulators irrespective of the indication and usually for short term [19]. Kalampokas et al. reviewed the UPA mechanism of action and its efficiency for the uterine fibroids treatment, but the effects on intact endometrial which is still exposed to normal unopposed levels of circulating oestrogens were not addressed [20]. UPA action as emergency contraception was appraised by Rosato et al. [21] and Gemzell-Danielsson. They did not approach the issue of more extended exposure to UPA [22].

A more recent review performed by de Milliano et al. [23] focused on the effects and safety on endometrium of the UPA, administrated for various reasons as contraception and short or long term for symptomatic fibroids, followed or not by surgery. The authors concluded that there were no non-reversible (pre-) malignant lesions of the endometrium even after 4 courses of therapy and that the PAEC changes seem not to be related to the dose or length of the treatment. Their conclusion was based mainly on the study of Williams et al. [9] and Donnez et al. [15], reporting percentages of endometrial hyperplasia of $0.4 \%$ to $4.5 \%$ during the follow-up period after UPA.

Our results are concordant with those reported by de Milliano concerning no premalignant or malignant lesion found after UPA, irrespective of the dosage and length of the treatment [23]. But we also found evidences that the proliferative expression of the endometrial was low, so the typically UPA-induced anomalies of the endometrium are not ominous [24-26]. The study of Whitaker et al., although limited in size, is important as it performs more than a histological evaluation of the endometrium and targets a more specific indicator of the proliferation by assessing gene expressions consistent with UPA acting as a PR antagonist. The study indicates that there is no proliferative activity in the endometrium after UPA administration.

\section{Conclusions}

The data provided by the literature review indicate that there is no risk of premalignant or malignant endometrial lesion irrespective of dose or length of the course treatment with UPA.

There is consistent evidence that the non-physiological changes PAEC related to UPA treatment are benign and complete reversible after treatment. 
FARMACIA, 2018, Vol. 66, 5

Considering the high efficiency of the UPA in controlling the bleeding and the size of the fibroids, its use can increase; therefore the reassurance that it cannot be responsible for ominous endometrial changes is important.

Our recommendation for further studies is to perform baseline, after treatment biopsies, but also follow up biopsies in order to exclude overlooked endometrial malignancies.

UPA can be prescribed for conservative treatment of fibroids in order to preserve fertility for an extended period, so it is important to continue the evaluation of its safety on long courses.

\section{References}

1. Philibert D, RU38486: An original multifaceted anti hormone in vivo. In Agarwal M (ed.) Adrenal Steroid Antagonism. Walter de Gruyter and Co, Berlin, 1984; 77-101.

2. Elger W, Bartley J, Schneider B, Kaufmann G, Schubert G, Endocrine pharmacological characterization of progesterone antagonists and progesterone receptor modulators with respect to PR agonistic and antagonistic activity. Steroids, 2000; 65:713-723.

3. Spitz IM, Progesterone antagonists and progesterone receptor modulators: an overview. Steroids, 2003; 68: 981-993.

4. Chabbert-Buffet N, Meduri G, Bouchard P, Spitz I, Selective progesterone receptor modulators and progesterone antagonists: mechanisms of action and clinical applications. Human Reproduction Update, 2005; 11(3): 293-307.

5. Chabbert-Buffet N, Pintiaux-Kairis A, Bouchard P, Group VAS, Effects of the progesterone receptor modulator VA2914 in a continuous low dose on the hypothalamic-pituitary-ovarian axis and endometrium in normal women: a prospective, randomized, placebocontrolled trial. J Clin Endocrinol Metab., 2007; 92(9): 3582-3589.

6. Donnez J, Tatarchuk TF, Bouchard P, Puscasiu L, Zakharenko NF, Ivanova T, Ulipristal acetate versus placebo for fibroid treatment before surgery. $N \mathrm{Engl}$ J Med., 2012; 366(5): 409-420.

7. Donnez J, Tomaszewski J, Vazquez F, Bouchard P, Lemieszczuk B, Baro F, Ulipristal 366 acetate versus leuprolide acetate for uterine fibroids. $N$ Engl J Med., 2012; 366(5): 421-432.

8. Mutter G, Bergeron C, Deligdisch L, Ferenczy A, Glant $\mathrm{M}$, Merino M, The spectrum of endometrial pathology induced by progesterone receptor modulators. Modern Pathology, 2008; 21(5): 591-598.

9. Williams AR, Bergeron C, Barlow DH, Ferenczy A, Endometrial morphology after treatment of uterine fibroids with the selective progesterone receptor modulator, ulipristal acetate. Int J Gynecol Pathol., 2012; 31(6): 556-569.

10. Liberati A, Altman DG, Tetzlaff J, Mulrow C, Gotzsche PC, Ioannidis JP, The PRISMA statement for reporting systematic reviews and meta-analyses of studies that evaluate health care interventions: explanation and elaboration. PLoS Med., 2009; 6(7): e1000100: 1-28.
11. Higgins JPT GSe. Cochrane Handbook for Systematic Reviews of Interventions 2011; Version 381 5.1.0.

12. Jepsen P, Johnsen SP, Gillman MW, Sørensen HT, Interpretation of observational studies. Heart, 2004; 90(8): 956-960.

13. Levens ED, Potlog-Nahari C, Armstrong AY, Wesley R, CDB-2914 for uterine leiomyomata treatment: a randomized controlled trial. Obstet Gynecol., 2008; 111(5): 1129-1136.

14. Donnez J, Vazquez F, Tomaszewski J, Nouri K, Bouchard P, Fauser BC, Long-term treatment of uterine fibroids with ulipristal acetate. Fertil Steril., 2014; 101(6): 1565-1573.

15. Donnez J, Hudecek R, Donnez O, Matule D, Arhendt HJ, Efficacy and safety of repeated use of ulipristal acetate in uterine fibroids. Fertil Steril., 2015; 103(2): 519-527.

16. Segal T, Zarek S, Mumford S, Plowden T, Nieman L, Segars J, Radiographic and histopathologic endometrial characteristics of women undergoing treatment with ulipristal acetate (UPA). Fertility and Sterility, 2014; 102(3): e286.

17. Simon J, Catherino W, Segars J, Blakesley R, Chan A, First US-based phase 3 study of ulipristal acetate (UPA) for symptomatic uterine fibroids (UF): results of VENUS-I. Fertility and Sterility, 2016; 106(3): e376.

18. Whitaker LH, Murray AA, Matthews R, Shaw G, Selective progesterone receptor modulator (SPRM) ulipristal acetate (UPA) and its effects on the human endometrium. Hum Reprod., 2017; 32(3): 531-543.

19. Wagenfeld A, Saunders PT, Whitaker L, Critchley HO, Selective progesterone receptor modulators (SPRMs): progesterone receptor action, mode of action on the endometrium and treatment options in gynecological therapies. Exp Opin Ther Targets, 2016; 20(9): 1045-1054.

20. Kalampokas T, Kamath M, Boutas I, Kalampokas E, Ulipristal acetate for uterine fibroids: a systematic review and meta-analysis. Gynecol Endocrinol., 2016; 32(2): 91-96.

21. Rosato E, Farris M, Bastianelli C, Mechanism of Action of Ulipristal Acetate for Emergency Contraception: A Systematic Review. Front Pharmacol., 2015; 6(Art. 315): 1-7.

22. Gemzell-Danielsson K, Berger C, Lalitkumar PGL, Emergency contraception - mechanisms of action. Contraception. 2013; 87(3): 300-308.

23. De Milliano I, Van Hattum D, Ket JCF, Huirne JAF, Hehenkamp WJK, Endometrial changes during ulipristal acetate use: A systematic review. Eur J Obstet Gynecol Reprod Biol., 2017; 214: 56-64.

24. Mehedinţu C, Brătilă E, Cîrstoiu M, Vlădăreanu R, Antonovici MR, Brîndușe LA, Berceanu C, Gherghiceanu F, Navolan D, Ionescu OM, Criveanu $\mathrm{M}$, A fixed herbal combination - A new approach in HPV cervical infection treatment. Farmacia, 2018; 66(3): 502-506.

25. Bălălău DO. Sima RM, Bacalbasa N, Banu P, Bălălău C, Ples L, Stanescu AD, High-grade cervical dysplasia in pregnancy - psychological and medical challenges. J Mind Med Sci., 2017; 4(1): 24-30.

26. Zaharescu I, Moldovan AD, Tanase C, Natural killer (NK) cells and their involvement in different types of cancer. Current status of clinical research. J Mind Med Sci., 2017; 4(1): 31-37. 